\title{
Co-treatment of Brazilein Enhances Cytotoxicity of Doxorubicin on WiDr Colorectal Cancer Cells Through Cell Cycle Arrest
}

\author{
Diah Tri Utami ${ }^{1,2}$, Nadzifa Nugraheni ${ }^{2}$, Riris Istighfari Jenie ${ }^{2,3}$, Edy Meiyanto ${ }^{2,3, *}$ \\ ${ }^{1}$ Department of Pharmacy, Faculty of Medicine and Health Science, Universitas Jambi, Jl. Raya Jambi - Muara Bulian KM.15, Mendalo Indah, \\ Jambi 36361, Indonesia \\ ${ }^{2}$ Cancer Chemoprevention Research Center, Faculty of Pharmacy, Universitas Gadjah Mada, Jl. Sekip Utara Sleman, Yogyakarta 55281, Indonesia \\ ${ }^{3}$ Laboratory of Macromolecular Engineering, Department of Pharmaceutical Chemistry, Faculty of Pharmacy, Universitas Gadjah Mada, \\ Jl. Sekip Utara Sleman, Yogyakarta 55281, Indonesia \\ *Corresponding author. E-mail: edy_meiyanto@ugm.ac.id
}

Received date: May 31, 2020; Revised date: Oct 12, 2020; Accepted date: Oct 13, 2020

\section{Abstract}

B ACKGROUND: The presence of adverse side effects limits the use of doxorubicin (Dox) despite its cost-effectiveness compared to other chemotherapeutic agents. Brazilein $(\mathrm{Be})$, the major compound of Caesalpinia sappan, performs cochemotherapeutic potency in several cancer cell lines. This study evaluates the chemosensitizing effects of Be to Dox on colon cancer cell line, WiDr.

METHODS: The 3-(4,5-dimethylthiazol-2-yl)-2,5diphenyl-2H-tetrazolium bromide (MTT) assay was conducted to evaluate the cytotoxic effect of Be and its combination with Dox. The synergistic effect of Be and Dox was examined by using the Combination index (CI) parameter. Cell cycle and apoptosis profiles were done using flow cytometry with propidium iodide (PI)/RNase and Annexin V staining, respectively.

RESULTS: The combination of Dox and Be at half of $\mathrm{IC}_{50}$ on WiDr cells showed a synergistic effect with a combination index of 0.4 . Analysis of the cell cycle revealed that the combination caused cell cycle termination at the $\mathrm{S}$ and $\mathrm{G} 2 / \mathrm{M}$ phase. This finding corresponded with the data that single treatment of Dox and Be induced cell cycle arrest at the different phases, namely $\mathrm{S}$ and $\mathrm{G} 2 / \mathrm{M}$ phase, respectively. However, the combination treatment for 24 hours did not induce apoptosis. This combination should be further clarified as there was a possibility that many cells may underwent permanently arrest that halts to proceed apoptosis.

CONCLUSION: Our findings suggested that Be synergizes with Dox to suppress the growth of WiDr cells via cell cycle arrest, hence, $\mathrm{Be}$ is potential to be developed as a cochemotherapeutic agent. Our findings suggested that $\mathrm{Be}$ synergizes with Dox to suppress the growth of WiDr cells via cell cycle arrest, hence, $\mathrm{Be}$ is potential to be developed as a co-chemotherapeutic agent.

KEYWORDS: Brazilein, colon cancer WiDr, co-treatment, Doxorubicin, cell cycle arrest

Indones Biomed J. 2020; 12(4): 376-83

\section{Introduction}

Doxorubicin (Dox), as one of the first lines of chemotherapeutic agents, is commonly used in the therapeutic regimens for several types of cancers.(1) In colon cancer, drug resistance is a cause of chemotherapy, including Dox. (2) Although Dox is not the primary chemotherapy for colon cancers because it is unstable by oral administration and its unexpected side effects, Dox is still the drug of choice due to its cost-effective.(3) The side effects of chemotherapy can be reduced through the application of combination therapy (4), which can be achieved by using natural agents with cytotoxic and anti-oxidant properties. Such this strategy may increase the efficacy of chemotherapy and reduce the unexpected side effects like toxicity on normal cells.(5) 
Moreover, the natural product application can act as a cellular chemoprotective against the destructive effect of chemotherapy (6), allowing it to be used in combination with doxorubicin. In many cases, 5 -fluorouracil (5-FU) is widely used to treat colon cancer, but it needs much more dose than Dox and raises more unexpected side effects.(7) On the other hand, Epirubicin, an enantiomer form of Dox, is used to replace Dox to avoid the resistance.(8) However, Epirubicin is much more expensive than Dox. Therefore, Dox combination with natural agents can be preferred to solve this problem of colon cancer.

This research is challenging the use of Brazilein (Be) combined with Dox to inhibit colon cancer cell proliferation. Be is an oxidative form of the Brazilin compound (Figure 1), which is abundantly contained in Sappan wood from Caesalpinia sappan. $(9,10)$ Be will be more abundant than Brazilin in the open-air conditions at room temperature due to oxidation from the air, so $\mathrm{Be}$ is preferred over Brazilin because it is more chemically stable. Brazilin and Be have investigated their anticancer activities, both in vitro and in vivo. Both compounds have vigorous cytotoxic activities in some cancer cells, such as MCF-7 (11), 4T1 (12), MCF-7/HER2 (13), MDA-MB (14), and other types of breast cancer cell line (15). The anticancer mechanism of the two compounds occurred through cell cycle arrest in the G2/M phase and apoptosis tracking (10) and can inhibit cancer cells' migration, which allows both compounds as anti-metastatic agents $(14,15)$. The two compounds also showed synergistic effects with cisplatin on WiDr colon cancer cells.(10) We also realized that Sappan wood extract exhibits aldose reductase inhibition that may increase reactive oxygen species (ROS) generation due to chemotherapeutic treatment.(16) Since ROS has a role in the malignant transformation of primary tumors to increase their metastatic potential (17), the increasing effect of Sappan wood extract will contribute to the cytotoxic activity of chemotherapeutic agents occur through senescence and

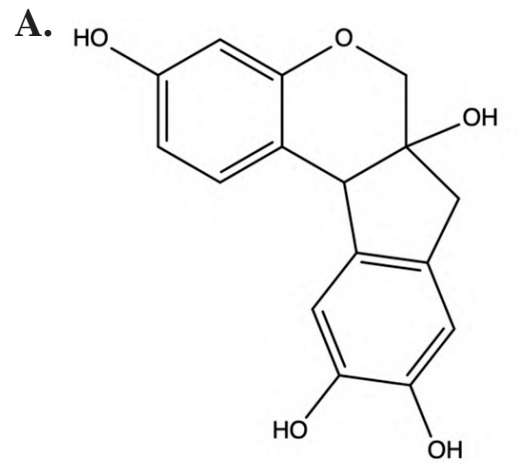

apoptosis. Therefore, Sappan compounds possess potential cytotoxic or co-chemotherapeutic activities. We propose that Be may increase the cytotoxic effect of Dox on colon cancer cells.

Colon or colorectal cancer is still an interesting issue in developing therapeutic research, including natural products. Colon cancer generally appears and shows symptoms when it reaches an advanced stage, making it more difficult to cure. $(18,19)$ The process of colorectal tumors progression from benign to malignant begins from the adenomatous polyposis coli (APC) gene followed by clonal expansion through the basement membrane, allowing colon cancer cells metastasize very quickly to reach distant organs. (20) Therefore, chemotherapy of colorectal cancer will be the foremost choice, although there remains the risk of unexpected side effects and the emergence of resistance.(21) Besides, colon cancer generally also causes inflammation and is metastatic.(22) With such phenomena, Be as a cochemotherapeutic agent for Dox is expected to overcome these problems, considering that $\mathrm{Be}$ also has strong antioxidant properties (23) that may reduce the inflammatory symptom of cancer (24). The WiDr cell used in this study is a colon cancer cell model that is characterized to be proliferative and metastatic.(25) This study aimed to evaluate Be's synergistic potential as a co-treatment of Dox against WiDr colon cancer cells, including its cytotoxic effects, cell cycle, and apoptosis in both single treatment and its combination with Dox. This study will be useful to provide scientific data for brazilein to be developed as cochemotherapy on colorectal cancer.

\section{Methods}

\section{Materials}

Be was provided by Cancer Chemoprevention Research Center (CCRC), Faculty of Pharmacy, Universitas Gadjah

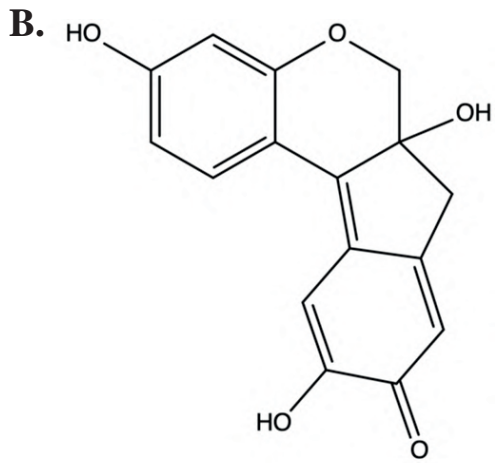

Figure 1. Chemical structures of Be (A) and Brazilin (B). 
Mada, Indonesia.(26) Be dissolved in dimethyl sulfoxide (DMSO) (DMSO pro GC, Sigma Aldrich Chemie gmBH, Steinheim, Germany) to reach a stock concentration of 1 $\mathrm{mM}$. Be was prepared by diluting the stock solution with the culture medium to reach the DMSO concentration below 0.1 $\%$ v/v. Dox (Combiphar/Pharmachemie, Jakarta, Indonesia) used as a chemotherapeutic agent.

\section{Cell Culture}

In this study, the WiDr cell line originally was obtained from Parasitology Laboratory, Faculty of Medicine, Universitas Gadjah Mada, Indonesia, and maintained by CCRC under American Type Culture Collection (ATCC) protocol. Cells were cultured at $37^{\circ} \mathrm{C}$ with a humidified incubator, $5 \% \mathrm{CO}_{2}$, in a suitable medium for WiDr cells Roswell Park Memorial Institute (RPMI) (Gibco, Waltham, MA, USA) supplemented with 10\% Fetal Bovine Serum (FBS) (Gibco), 10,000 units/ $\mathrm{mL}$ penicillin-10,000 $\mathrm{\mu g} / \mathrm{mL}$ streptomycin (Gibco).

\section{Cytotoxicity Assay}

Cytotoxicity of Be, Dox, and its combination on WiDr cells were determined using 3-(4,5-dimethylthiazol-2yl)-2,5-diphenyl-2H-tetrazolium bromide (MTT) assay. Cells were distributed into a 96-well plate with the density of $1 \times 10^{4}$ cells/well, then incubated in a $37^{\circ} \mathrm{C}$ incubator supplemented with $5 \% \mathrm{CO}_{2}$ for 24 hours. Be and Dox were diluted in culture medium using DMSO as co-solvent with concentration not more than $0.1 \% \mathrm{v} / \mathrm{v}$. After 24 hours of incubation, the culture medium was removed, followed by washing with phosphate-buffered saline (PBS). Then, 0.5 $\mathrm{mg} / \mathrm{mL}$ of MTT in PBS was added, followed by $4 \mathrm{~h}$ ours incubation in $37^{\circ} \mathrm{C}$ with $5 \% \mathrm{CO}_{2}$. After that, $10 \%$ sodium dodecyl sulfate (SDS) in $\mathrm{HCl} 0.01 \mathrm{~N}$ as a stopper reagent is then added overnight at room temperature. The absorbance was determined spectrophotometrically at $\lambda 595 \mathrm{~nm}$ on a microplate reader (Biorad Model 680, Hercules, CA, USA).

\section{Flow Cytometry}

Apoptosis and cell cycle analysis carried out using flow cytometry (BD FACSCalibur, BD, Franklin Lakes, NJ, USA). A $5 \times 10^{5}$ cells/well were cultured in 6 well plate and treated with $\mathrm{Be}\left(1 \times 10^{4} \mu \mathrm{g} / \mathrm{mL}\right)$, Dox $\left(3.68 \times 10^{3} \mu \mathrm{M}\right)$, and a combination of Be-Dox for 24 hours. After 24 hours, the cells were rinsed with PBS and centrifuged at $2000 \mathrm{rpm}$ for 5 minutes. The attached cells were detached with $200 \mu \mathrm{L}$ of trypsin-EDTA for 3 minutes, then added $1 \mathrm{~mL}$ of RPMI and centrifuged at $2000 \mathrm{rpm}$ for 5 minutes. For cell cycle analysis, the samples were added of $25 \mu \mathrm{L}$ propidium iodide (minimum 95\% high-performance liquid chromatography
(HPLC)) (Sigma-Aldrich, St. Louis, MO, USA), $2.5 \mu \mathrm{L}$ RNase, and $0.5 \mu \mathrm{L}$ Triton-X (triton X-100 for GC) (Merck, Darmstadt, Germany) in $500 \mu \mathrm{L}$ PBS and subjected for flow cytometry analysis after incubated for 10 minutes in darkness at a temperature of $37^{\circ} \mathrm{C}$. For apoptosis assay, the treated cells were stained using Annexin-FLUOS/PI staining kit as guided by the protocol kit (Roche, Basel, Switzerland). The treated cells were subjected to flow cytometry measurement, and data were analyzed using ModFit LT 4.0 software (Verity Software House, Topsham, ME, USA).

\section{Statistical Analysis}

All data expressed as mean and standard deviation (SD). Statistically significant differences were determined by student $t$ test with the significance consideration of $p<0.05$.

\section{Results}

\section{Cytotoxic Effects of Be and Dox}

Be has been deeply explored for its anticancer properties in several cancer types. We challenged Be to improve the cytotoxic activity of Dox against WiDr, colon cancer cells known to have p53 mutation, and resistance to Dox. Cytotoxic activity, as an initial evaluation at 24 hours treatment, revealed that Dox performed a high cytotoxic effect with the $\mathrm{IC}_{50}$ of $2 \mu \mathrm{M}$ (Figure $2 \mathrm{~B}$ ). In contrast, $\mathrm{Be}$ exhibited a weak cytotoxic activity with an $\mathrm{IC}_{50}$ value of $130 \mu \mathrm{M}$ (Figure 2A). Both compounds expressed a dosedependent effect against the tested cells, WiDr. They caused changes in the morphological appearance of cells at the relatively high doses of the respective compounds. These morphological changes, such as spherical shape and shrinkage of the cell membrane, perhaps correlate to the cells' physiological disruption. These are due to the treatment characterized as cell arrest or cell death.

\section{Synergistic Effect of Be and Dox}

Dox was expected to have an $\mathrm{IC}_{50}$ value in less than 1 $\mu \mathrm{M}$. This result indicated that the WiDr cells exhibited a resistance phenomenon to Dox. On the other hand, Be is not strong enough to have a cytotoxic effect on WiDr cells. Therefore we conducted a co-treatment between Dox and Be on WiDr cells in the respected series of concentration. We found that the increasing concentration of the co-treatment results in the more decreasing cell viabilities (Table 1). The most potent effect, which shows approximately $55 \%$ of cell viability, was performed at the Dox $1 \mu \mathrm{M}$ (half of 
A.
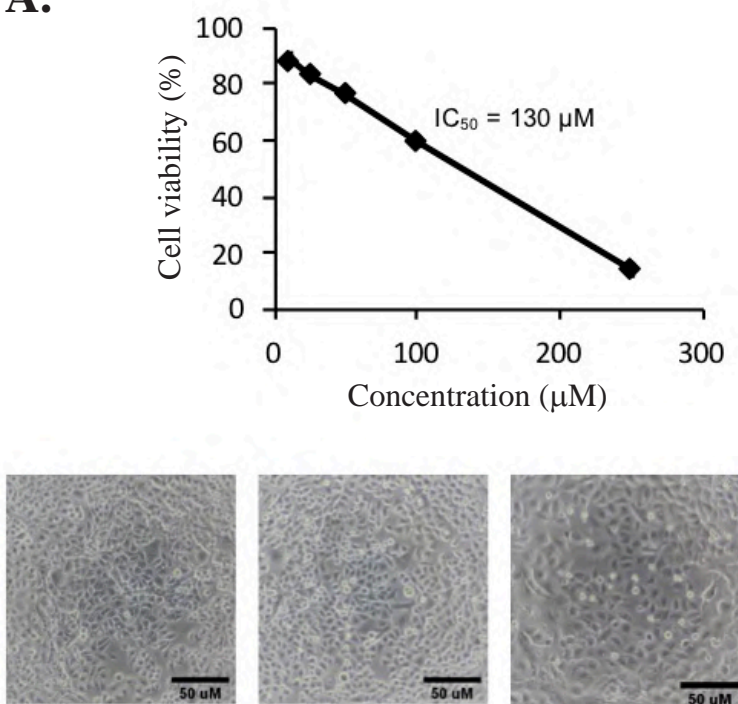

Untreated

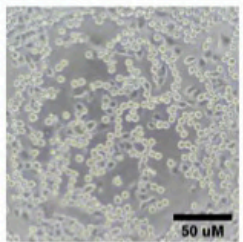

Brazilein $50 \mu \mathrm{M}$

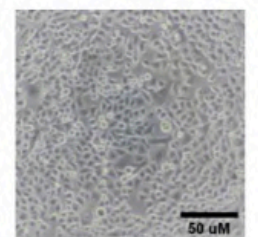

Brazilein $10 \mu \mathrm{M}$

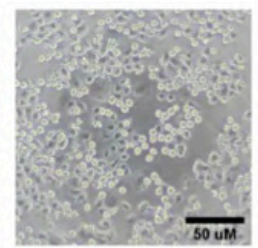

Brazilein $100 \mu \mathrm{M}$

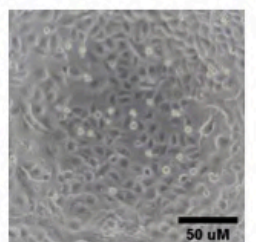

Brazilein $25 \mu \mathrm{M}$

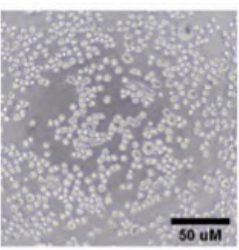

Brazilein $250 \mu \mathrm{M}$

B.

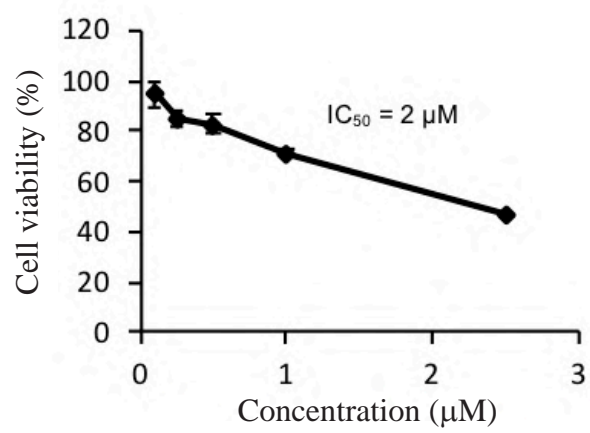

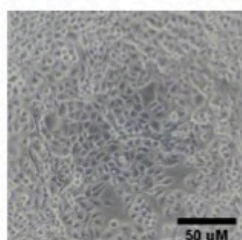

Untreated

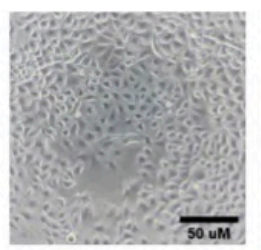

Doxorubicin $0.5 \mu \mathrm{M}$

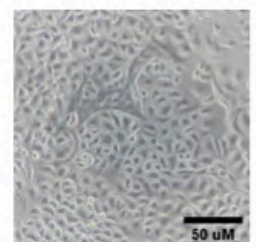

Doxorubicin $0.25 \mu \mathrm{M}$

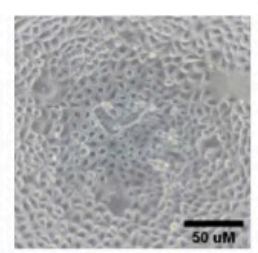

Doxorubicin $1 \mu \mathrm{M}$

Figure 2. Cytotoxic effect of Be and Dox. WiDr cells were treated with serial concentrations of Be and Dox for 24 hours and subjected to MTT assay as described in the method. A: Cells viability profile of Be 1-250 $\mu \mathrm{M}$ treatment; B: Cells viability profile of Dox 1-3 $\mu \mathrm{M}$ treatment. Be gives $\mathrm{IC}_{50}$ value of $130 \mu \mathrm{M}$ while Dox was $2 \mu \mathrm{M}$. Cell viability profile is shown as a means \pm SD of 3 experiments. The linear regressions were calculated with a $p$-value $<0.05$

$\mathrm{IC}_{50}$ ) with $\mathrm{Be} 65 \mu \mathrm{M}$ (half of $\mathrm{IC}_{50}$ ). The co-treatment of high concentrations of Dox $(0.5$ and $1 \mu \mathrm{M})$ and Be $(32.5$ and $65 \mu \mathrm{M}$ ) showed synergistic effects (Table 2). This result indicates that $\mathrm{Be}$ can be used for co-treatment to increase the cytotoxic effect of Dox on WiDr cells.

\section{Cell Cycle Modulation Effects of Be and Dox}

The further assay was done by flow cytometry to assess the correlation between the cytotoxic property of the synergistic effect with cell cycle distribution profiles caused by Be, Dox, and their combination. The previous study claimed that Dox could induce cell cycle arrest in S, G1, and G2/M phases in some cancer cells. Simultaneously, the Be performed to induce cell cycle arrest in S and G2/M phases. The result illustrated that Be caused cell accumulation in $\mathrm{S}$ phase; meanwhile, treated with Dox caused cell accumulation in $\mathrm{S}$ and G2/M phase (Figure 3). Interestingly co-treatment of the two agents caused cell accumulation in the S phase but mainly in the G2/M phase, which is higher than single Dox treatment (Figure 3). The cell cycle arrest with incredible evidence may cause cell death by introducing apoptosis that should be clarified further.

Table 1. The cell viability profiles of combination treatment of brazilein and Dox at sub $\mathrm{IC}_{50}$ concentration.

\begin{tabular}{lcccc}
\hline \multirow{2}{*}{$\begin{array}{c}\text { Concentration of } \\
\text { Brazilein }(\boldsymbol{\mu M})\end{array}$} & \multicolumn{4}{c}{ Concentration of Doxorubicin $(\boldsymbol{\mu M})$} \\
\cline { 2 - 5 } \multicolumn{0}{c}{} & $\mathbf{0}$ & $\mathbf{0 . 2 5}$ & $\mathbf{0 . 5}$ & $\mathbf{1}$ \\
$\mathbf{1 6 . 2 5}$ & 100 & 94.28 & 93.69 & 80.68 \\
$\mathbf{3 2 . 5}$ & 84.96 & 89.15 & 85.15 & 71.18 \\
$\mathbf{6 5}$ & 83.44 & 85.3 & 80.11 & 64.48 \\
\hline
\end{tabular}


Table 2. Combination Index (CI) analysis of Dox with Be indicated that the combination act synergistically.

\begin{tabular}{lccc}
\hline \multirow{2}{*}{$\begin{array}{c}\text { Concentration of } \\
\text { Brazilein }(\boldsymbol{\mu M})\end{array}$} & \multicolumn{3}{c}{$\begin{array}{c}\text { CI Values of Co-treatment with } \\
\text { Doxorubicin }(\boldsymbol{\mu M})\end{array}$} \\
\cline { 2 - 4 } & $\mathbf{0 . 2 5}$ & $\mathbf{0 . 5}$ & $\mathbf{1}$ \\
\hline $\mathbf{1 6 . 2 5}$ & 2.01 & 0.78 & 0.25 \\
$\mathbf{3 2 . 5}$ & 1.59 & 0.88 & 0.37 \\
$\mathbf{6 5}$ & 0.72 & 0.51 & 0.44 \\
\hline
\end{tabular}

\section{Effects of Be and Dox on Apoptosis}

We conducted flow cytometry analysis using Annexin V-FITC/PI staining to ascertain whether cell viability decreased despite cell cycle arrest and subsequent cell death. The result confirmed that Be could not increase cell death through apoptosis induction. However, it slightly increased necrosis cell death induced by Be in combination with Dox compared to the single treatment of Dox. A combination of Dox with Be and Dox alone (24 hours treatment) caused $18.2 \%$ and $25.24 \%$ cell death, respectively (Figure 4 ). Overall, these flow cytometry assessments of cell death confirmed that treatment of Dox in single and its cotreatment with Be-induced apoptosis were not significantly different.

\section{Discussion}

$\mathrm{Be}$ is the main component in Sappan wood known to have beneficial pharmacological effects such as anti-oxidant and anticancer. In this study, Be showed a weak cytotoxic effect on colon cancer, WiDr, but Be performed a synergistic effect with Dox. These results are promising for Be to be developed as a co-chemotherapeutic agent with Dox.

Dox was expected to have an $\mathrm{IC}_{50}$ value in less than $1 \mu \mathrm{M}$, as reported in its activities against other cancer cell lines. $(15,27)$ Co-treatment with Dox is expected to increase the effectiveness of Dox, especially in dealing with colon cancer, because so far, several colon cancer therapy regimens have not been able to overcome the growing problem of resistance to colon cancer. $(18,28)$ Dox is not currently an option for colon cancer therapy because Dox also has resistance problems and side effects that are difficult to avoid and have stability problems for oral use. (29) However, Dox is a chemotherapeutic agent relatively inexpensive, which is still expected to be used to cure cancer. Be can be easily obtained because of its abundant availability in Sappan wood $(10,30,31)$; hence, it can be used as complementary medicine to overcome Dox's problem.
A.
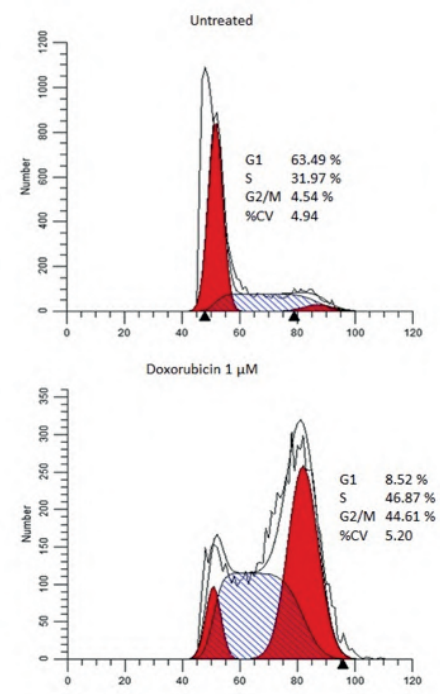
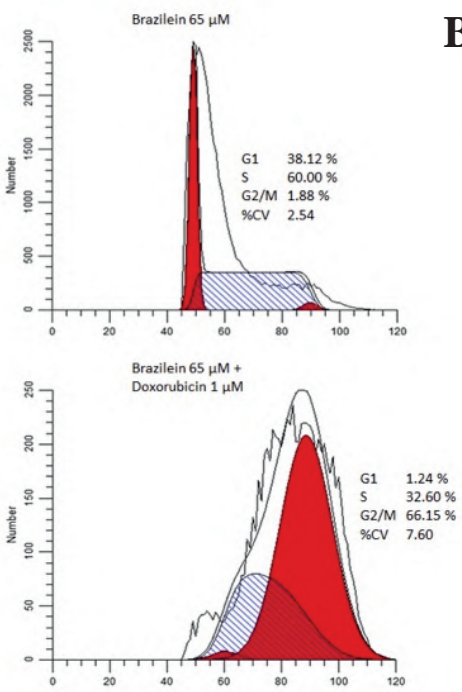

B.

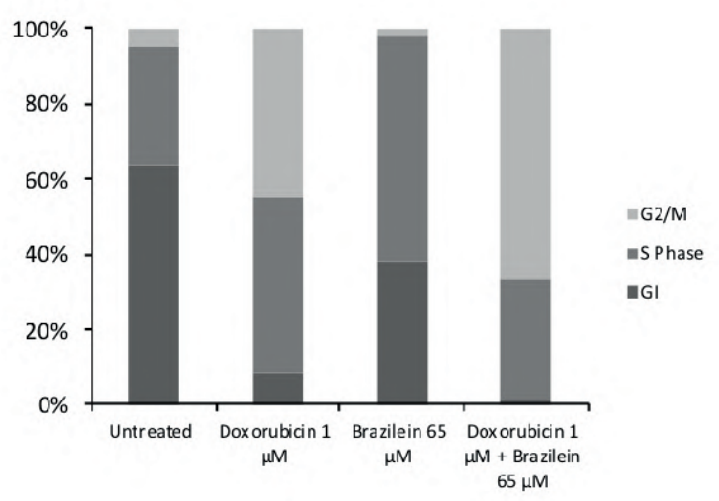

Figure 3. Dox in combination with Be caused the changing of cell cycle distribution on WiDr cells. Cells were treated for 24 hours with Be, Dox, and its combination and subjected for flow cytometry analysis after stained with propidium iodide/RNase. A: Flow cytogram of cell cycle profiles; B: Quantification of cell cycle distribution. 

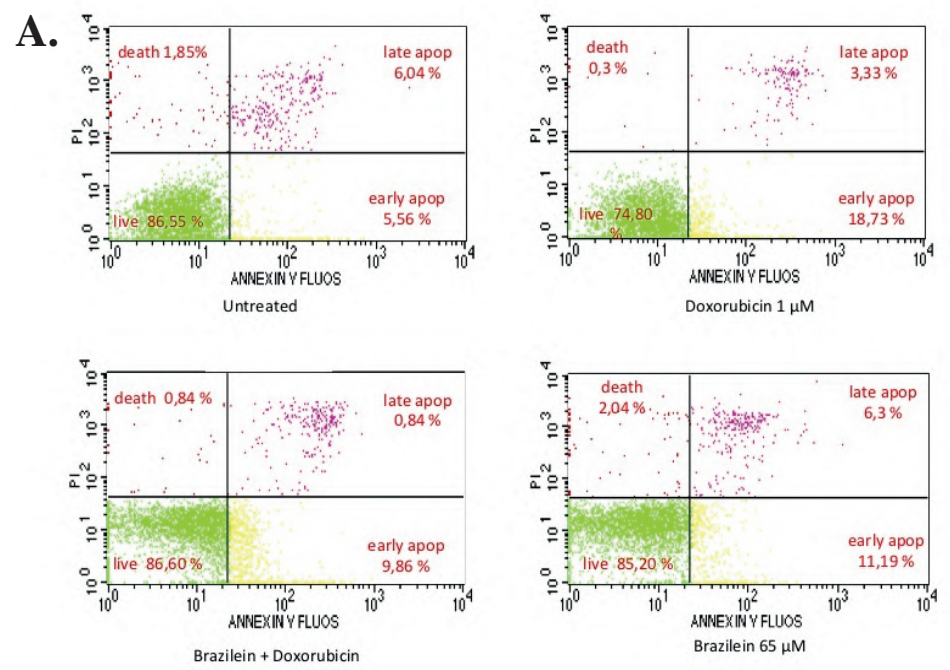

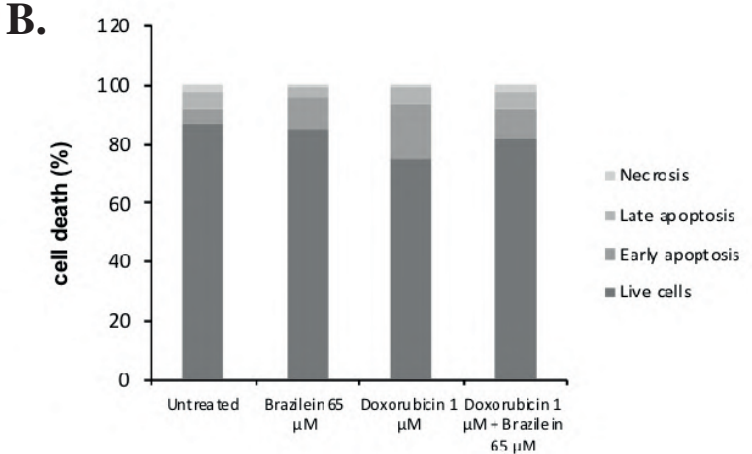

Figure 4. Be, Dox, and its combination induced apoptosis cells on WiDr cells. Cells were treated for 24 hours with Be, Dox, and its combination in the respected concentration and subjected for flow cytometry analysis using annexin V-FITC/PI staining. A: Flowcytogram profiles of treated cells; B: Quantification of cells death population of treated cells.

The synergistic effect of Be with Dox on WiDr cells seems to be related to the induction of apoptosis and cell cycle arrest, primarily in the $\mathrm{S}$ and $\mathrm{G} 2 / \mathrm{M}$ phases. These results are consistent with the results previously reported that $\mathrm{Be}$ tended to cause cell cycle arrest in the $\mathrm{G} 2 / \mathrm{M}$ phase (12), while Dox causes the termination of cell cycle mainly in the $\mathrm{S}$ phase by blocking the topoisomerase II enzyme $(10,32)$. The combination of the two agents shows extreme cell cycle termination in both phases, $\mathrm{S}$ and $\mathrm{G} 2 / \mathrm{M}$, causing many cells to fail to divide, and consequently, the cell viability drops sharply. This experiment is carried out within 24 hours, which is the average time of one round of cell division. Furthermore, the assay is necessary for a more complete result to explore the effects at a much longer time.

The inhibitory effect of $\mathrm{Be}$ in cell cycle progression seems to be typical for various cancer cells $(11,23)$, which is generally continue to occur apoptosis (15). However, the effect of cell cycle arrest of co-treatment of Be and Dox on WiDr cells does not appear to be related to apoptotic induction. These were seen in the Flow cytometry analysis (Figure 3), which did not show a significant difference in the number of cell populations that underwent death between Dox and combination treatment (Dox $+\mathrm{Be})$. These events can be caused by insufficient observation time, or many cells with a permanent arrest did not execute into apoptosis.

For this reason, it is necessary to clarify whether the combination treatment of Dox + Be will increase senescent evidence, which is a phenomenon of permanent cell cycle arrest. Observations on this experiment were carried out over 24 hours for a condition of the cells that allows arrest cells to change in different cell cycle phases, namely $\mathrm{S}$ and G2/M phases, each of which may be caused by Dox and Be. It seems that Dox and Be carried out their effects sequentially, even though there was a significant decrease in cell population arrest in the $\mathrm{S}$ phase. This occurrence could be due to the anti-oxidant property of Be which could counteract the increase in intracellular ROS caused by Dox. However, cells that pass the $\mathrm{S}$ phase will be hampered by Be's progression to stop at the $\mathrm{G} 2 / \mathrm{M}$ phase. This event is interesting to explore further in the future.

The in vivo toxicity evaluation of the Sappan wood extract showed its safety nature, and it can be recommended to use in consumer products. The previous study of acute toxicity to rats revealed that Sappan wood showed no toxicity evidence in general behavior change, mortality, or change in the gross appearance of internal organs up to the dose of $5000 \mathrm{mg} / \mathrm{kg}$.(33) Moreover, Sappan wood extract showed no clinical signs of toxicity and no mortality in Wister albino rats even at a dose level of $100-2000 \mathrm{mg} / \mathrm{kg}$ after a 14 days observation period.(34) When a dose level above $2500 \mathrm{mg} / \mathrm{kg}$ was given for 28 days, no death was noticed up to the dose level of $5000 \mathrm{mg} / \mathrm{kg}$ body weight. Sappan wood extract did not produce any acute or subacute toxicity in female and male rats.(34) Besides, Sappan wood has been used as traditional medicine and herbs drinking formula. Sappan wood also often consumes to boost the immune response. Therefore, Sappan wood should be safe and suitable for healthy cells, but it can inhibit cancer cell proliferation in a particular or relatively high concentration. Overall, this study provides impressive results suggesting that Be has the potential to be used as a co-chemotherapeutic agent for Dox, particularly for colon cancer. Be has a 
potential activity to suppress Dox side effects caused by increased intracellular ROS, but Be still has a synergistic cytotoxic effect with Dox. For this reason, the effect of intracellular ROS modulation by Be needs to be further investigated concerning the effects of senescence and apoptosis on healthy cells and cancer cells to determine a clearer mechanism. WiDr as a model of colon cancer is metastatic, and Be shows the potential to inhibit cell migration in breast cancer.(12,26) Therefore, Be can further explore its inhibitory effect on the metastatic process and colon cancer migration. Be is a compound that is abundant in sappan wood so that in practical use, it can be an extract that is standardized against the content of Be.

\section{Conclusion}

Be possesses low cytotoxic property toward WiDr, colon cancer cell line, but Be can increase the cytotoxic activity of Dox by enhancing cell cycle arrest at $\mathrm{G} 2 / \mathrm{M}$, providing the prospect of Be for co-chemotherapeutic application against colon cancer.

\section{Acknowledgements}

This research was supported by the Cancer Chemoprevention Research Center (CCRC) project, Faculty of Pharmacy Universitas Gadjah Mada, Yogyakarta, Indonesia.

\section{References}

1. Taymaz-Nikerel H, Karabekmez ME, Eraslan S, Kirdar B. Doxorubicin induces an extensive transcriptional and metabolic rewiring in yeast cells. Sci Rep. 2018; 8: 1-14.

2. Hu T, Li Z, Gao CY, Cho CH. Mechanisms of drug resistance in colon cancer and its therapeutic strategies. World J Gastroenterol. 2016; 22: 6876-89.

3. Sonowal H, Pal PB, Wen JJ, Awasthi S, Ramana K V., Srivastava SK. Aldose reductase inhibitor increases doxorubicin-sensitivity of colon cancer cells and decreases cardiotoxicity. Sci Rep. 2017; 7: $1-14$.

4. Mokhtari RB, Homayouni TS, Baluch N, Morgatskaya E, Kumar S, Das B, et al. Combination therapy in combating cancer. Oncotarget. 2017; 8: 38022-43.

5. Zhang QY, Wang FX, Jia KK, Kong LD. Natural product interventions for chemotherapy and radiotherapy-induced side effects. Front Pharmacol. 2018; 9: 1253. doi: 10.3389/fphar.2018.01253.

6. Rejhová A, Opattová A, Čumová A, Slíva D, Vodička P. Natural compounds and combination therapy in colorectal cancer treatment. Eur J Med Chem. 2018; 144: 582-94.

7. Lim KH, Han SW, Oh DY, Im SA, Kim TY, Bang YJ. Outcome of infusional 5-fluorouracil, doxorubicin, and mitomycin-C (iFAM) chemotherapy and analysis of prognostic factors in patients with refractory advanced biliary tract cancer. Oncol. 2012; 83: 57-66.

8. Khasraw M, Bell R, Dang C. Epirubicin: Is it like doxorubicin in breast cancer? A clinical review. Breast. 2012; 21: 142-9.

9. Nirmal NP, Rajput MS, Prasad RGSV, Ahmad M. Brazilin from Caesalpinia sappan heartwood and its pharmacological activities: A review. Asian Pac J Trop Med. 2015; 8: 421-30.

10. Handayani S, Susidarti RA, Jenie RI, Meiyanto E. Two active compounds from Caesalpinia sappan L. in combination with cisplatin synergistically induce apoptosis and cell cycle arrest on WiDr cells. Adv Pharm Bull. 2017; 7: 375-80.

11. Rachmady R, Muntafiah L, Rosyadi F, Sholihah I, Handayani S, Jenie RI. Antiproliferative effect of secang heartwood ethanolic extract (Caesalpinia sappan L.) on HER2-positive breast cancer cells. Indones J Cancer Chemoprevention. 2017; 7: 1-5.

12. Handayani S, Susidarti RA, Udin Z, Meiyanto E, Jenie RI. Brazilein in combination with cisplatin inhibit proliferation and migration on highly metastatic cancer cells, 4T1. Indones J Biotechnol. 2016; 21: 38-47.

13. Jenie RI, Handayani S, Susidarti RA, Udin LZ, Meiyanto E. The cytotoxic and antimigratory activity of Brazilin-doxorubicin on MCF-7/HER2 cells. Adv Pharm Bull. 2018; 8: 507-16.

14. Hsieh CY, Tsai PC, Chu CL, Chang FR, Chang L Sen, Wu YC, et al. Brazilein suppresses migration and invasion of MDA-MB-231 breast cancer cells. Chem Biol Interact. 2013; 204: 105-15.

15. Utomo RY, Novarina A, Tirtanirmala P, Kastian RF, Jenie RI Enhancement of cytotoxicity and apoptosis induction of Doxorubicin by Brazilein containing fraction of secang (Caesalpinia sappan L.) on T47D Cells. Indones J Cancer Chemoprevention. 2018; 9: 32-40.

16. Li WL, Zheng HC, Bukuru J, De Kimpe N. Natural medicines used in the traditional Chinese medical system for therapy of diabetes mellitus. J Ethnopharmacol. 2004; 92: 1-21.

17. Meiliana A, Dewi NM, Wijaya A. Red meats and processed meat as the carcinogenic foods and phytochemical-chemoprevention. Indones Biomed J. 2019; 11: 225-39.

18. Meiliana A, Dewi NM, Wijaya A. The immunobiology of cancer: an update review. Indones Biomed J. 2017; 9: 53-72.

19. Van Der Jeught K, Xu HC, Li YJ, Lu X Bin, Ji G. Drug resistance and new therapies in colorectal cancer. World J Gastroenterol. 2018; 24 3834-48.

19. Strum WB. Unrequited returns in asymptomatic colorectal cancer detection. Clin Surg. 2018; 3: 1995.

20. Nurgali K, Jagoe RT, Abalo R. Editorial: Adverse effects of cancer chemotherapy: Anything new to improve tolerance and reduce sequelae? Front Pharmacol. 2018; 9: 1-3.

21. Pretzsch E, Bösch F, Neumann J, Ganschow P, Bazhin A, Guba M, et al. Mechanisms of metastasis in colorectal cancer and metastatic organotropism: hematogenous versus peritoneal spread. Journal of oncology. 2019; 2019: 7407190. doi: 10.1155/2019/7407190.

22. Liang CH, Chan LP, Chou TH, Chiang FY, Yen CM, Chen PJ, et al. Brazilein from Caesalpinia sappan L. antioxidant inhibits adipocyte differentiation and induces apoptosis through caspase-3 activity and anthelmintic activities against Hymenolepis nana and Anisakis simplex. Evid Based Complementary Alter. Med. 2013; 2013: 864892. doi: 10.1155/2013/864892.

23. Shen J, Zhang H, Lin H, Su H, Xing D, Du L. Brazilein protects the brain against focal cerebral ischemia reperfusion injury correlating to inflammatory response suppression. Eur J Pharmacol. 2007; 558: 88-95.

24. Kim YS, Ahn YH, Song KJ, Kang JG, Lee JH, Jeon SK, et al. Overexpression and $\beta-1,6-\mathrm{N}$-Acetylglucosaminylation-initiated 
aberrant glycosylation of TIMP-1: A “double whammy" strategy in colon cancer progression. J Biol Chem. 2012; 287: 32467-78.

25. Linda Laksmiani NP, Asmah Susidarti R, Meiyanto E. Brazilein increases the sensitivity of doxorubicin on MCF-7 resistant doxorubicin (MCF-7/DOX) cells through inhibition of HER-2 activation. Int J Pharm Pharm Sci. 2015; 7: 525-8.

26. Wulandari N, Meiftasari A, Fadliyah H, Jenie RI. Red betel leaves methanolic extract (Piper crocatum Ruiz \& Pav.) increases cytotoxic effect of Doxorubicin on WiDr colon cancer cells through apoptosis induction. Indones J Cancer Chemoprev. 2018; 9(1): 1-8.

27. Warkhade AA, Awad AH, Bhagat A, Karuppayil SM. Synergistic activation of Doxorubicin against cancer: A review. Am J Clin Microbiol Antimicrob. 2018; 1: 1009.

28. Xiong S, Xiao GW. Reverting doxorubicin resistance in colon cancer by targeting a key signaling protein, steroid receptor coactivator. Exp Ther Med. 2018; 15: 3751-8.

29. Meiyanto E, Larasati YA. The chemopreventive activity of Indonesia medicinal plants targeting on hallmarks of cancer. Adv Pharm Bull.
2019; 9: 219-30.

30. Meiyanto E, Lestari B, Sugiyanto RN, Jenie RI, Utomo RY, Sasmito $\mathrm{E}$, et al. Caesalpinia sappan L. heartwood ethanolic extract exerts genotoxic inhibitory and cytotoxic effects. Orient Pharm Exp Med. 2019; 19: 27-36.

31. Anders CK, Adamo B, Karginova O, Deal AM, Rawal S, Darr D, et al. Pharmacokinetics and efficacy of PEGylated liposomal Doxorubicin in an intracranial model of breast cancer. PLoS One. 2013; 8: e61359.

32. Taymaz-Nikerel H, Karabekmez ME, Eraslan S, Kurdar B. Doxorubicin induces an extensive transcriptional and metabolic rewiring in yeast cells. Sci Rep. 2018; 8: 1-4.

33. Sireeratawong S, Piyabhan P, Singhalak T, Wongkrajang Y, Temsiririrkkul R, Punsrirat J, et al. Toxicity evaluation of sappan wood extract in rats. J Med Assoc Thai. 2011; 93: S50-7.

34. Athinarayanana G, Ranjitsingh AJ, Padmalatha C. Toxicological studies of Caesalpinia sappan wood derived dye in Wister albino rats. Food Science and Human Wellness. 2017; 6: 34-8. 